\title{
Towards a Five-Step Institutional Income Diversification Strategy for Institutions of Higher Education
}

\author{
Samuel H. Baligidde ${ }^{1}$
}

(C) Uganda Martyrs University

\begin{abstract}
This paper discusses the strategic perspectives of financial management which are highlighted in a five-step Institutional Income Diversification Model for Institutions of Higher Education. It focuses on the need for adopting or strengthening corporate principles of financial management, corporate methods of raising capital, establishment of income generating activities, strategic acquisitions, institutional mergers, establishment of commercial projects, treating higher education as an export and involving students and other stakeholders in the financial resource mobilization drive. It argues that, in order to tackle the challenge of inadequate funding, Institutions of Higher Education should re-examine their priorities, re-organize their financial management structures, re-orient their administrative processes and diversify their income sources. This will necessitate a change from the highly bureaucratic organizational design of most of the institutions to a corporate model that pays attention to market forces and private sector principles of financial management.
\end{abstract}

Keywords $\cdot$ Higher education $\cdot$ Funding $\cdot$ Institutional management

Vers une Stratégie a Cinq Etapes pour une Diversification Institutionnelle de Revenu pour les Institutions d'Enseignement Supérieur - Résumé - Cet article argumente les perspectives stratégiques de la gestion financière qui sont présentées dans un model à cinq étapes pour la diversification institutionnelle de revenu pour les institutions d'enseignement supérieur. Il s'articule sur le besoin d'adopter ou renforcer les communs principes de la gestion financière, les méthodes communes pour amasser le capital, l'établissement des activités génératrices de revenu, les acquisitions stratégiques, les agglomérations institutionnelles, l'établissement de projets commerciaux, traiter l'enseignement supérieur comme un export et engager les étudiants ainsi qu'autres parties concernées dans la force de mobilisation de ressources financiers. Il a été démontré que, afin de résoudre le défi du financement inadéquat, les institutions d'enseignement supérieur doivent réexaminer leurs priorités, réorganiser leurs structures de gestion financière, réorienter leurs procédures administratives et diversifier leurs sources de revenu. Ceci va nécessiter un changement de model organisationnel hautement bureaucratique de nombreuses des institutions à un commun model qui fait attention aux forces du marché et aux principes de gestion financière de secteur privé. Mots Clé. Enseignement supérieur $\cdot$ financement $\cdot$ gestation institutionnelle

\section{Introduction}

Inadequate funding for managing expansion in student enrolment against a background of inelastic physical and academic facilities, declining government and donor funding, are the greatest challenges responsible for undermining effectiveness in quality assurance. Institutions of Higher

\footnotetext{
${ }^{1}$ Uganda Martyrs University, E-mail: sbaligidde@umu.ac.ug
} 
Education ought to initiate strategies for diversifying their income sources. The strategic perspectives in which Institutions of Higher Education are managed are highlighted in a five-step Institutional Income Diversification Model, which focuses on the need for adopting or strengthening corporate principles of financial management, corporate methods of raising capital, establishment of income generating activities, strategic acquisitions, institutional mergers, establishment of commercial projects, treating higher education as an export, involving students and other stakeholders in the financial resource mobilization drive. The Five Step Model is based on the findings of a mini study, that used questionnaire and interview instruments, and which involved 30 Postgraduate students at Makerere University in 2005 and the experience as well as observations of the Author.

In order to tackle the challenge of inadequate funding Institutions of Higher Education should re-examine their priorities, re-organize their financial management structures, re-orient administrative processes and diversify their income sources. This will necessitate a change from the highly bureaucratic organizational design of most institutions to the corporate model that pays attention to market forces and private sector principles of financial management.

\section{Efficiency of Higher Education}

Efficiency concerns the relationship between inputs and outputs. In the context of quality assurance this would refer to the capacity of Universities to produce desired results with minimum expenditure of time, energy, money and materials. This relationship between output and input may seem obvious from a Government Economist's point of view but at times when funding is cut it is all too easy for the Government, Founding Bodies and Donor organizations to assume that resources can be cut without this affecting quality. It is equally likely that the declining fall in quality may in turn lead to the entire Higher Education System becoming less efficient. Austerity measures can lead to efficient financial management but are a drop in the ocean when huge budget deficits that require long term solutions are involved.

The liberalization and subsequent privatization of Higher Education was in tandem with the changes in the academic heartland of the Western World which would have been ignored at great peril. However, the East African Governments should not entirely divest themselves of responsibility. They have to institute enabling financial measures which encourage institutional autonomy and accountability. Financial mechanisms such as subvention capitation grants, vouchers, student loans should also be extended to chartered private institutions that have a proven record of quality whenever possible. Since the trend is towards government cuts in Public expenditure on Higher Education measures which encourage revenue diversification must be put in place. Institutions of Higher Education should be mandated to engage in income generating activities. Institutions of Higher Education ought to initiate strategies for diversifying their income sources in order to tackle the challenge of inadequate funds if they are to remain efficient and effective. This paper proposes a model for the diversification of revenue sources for both public and private institutions of higher Education. 


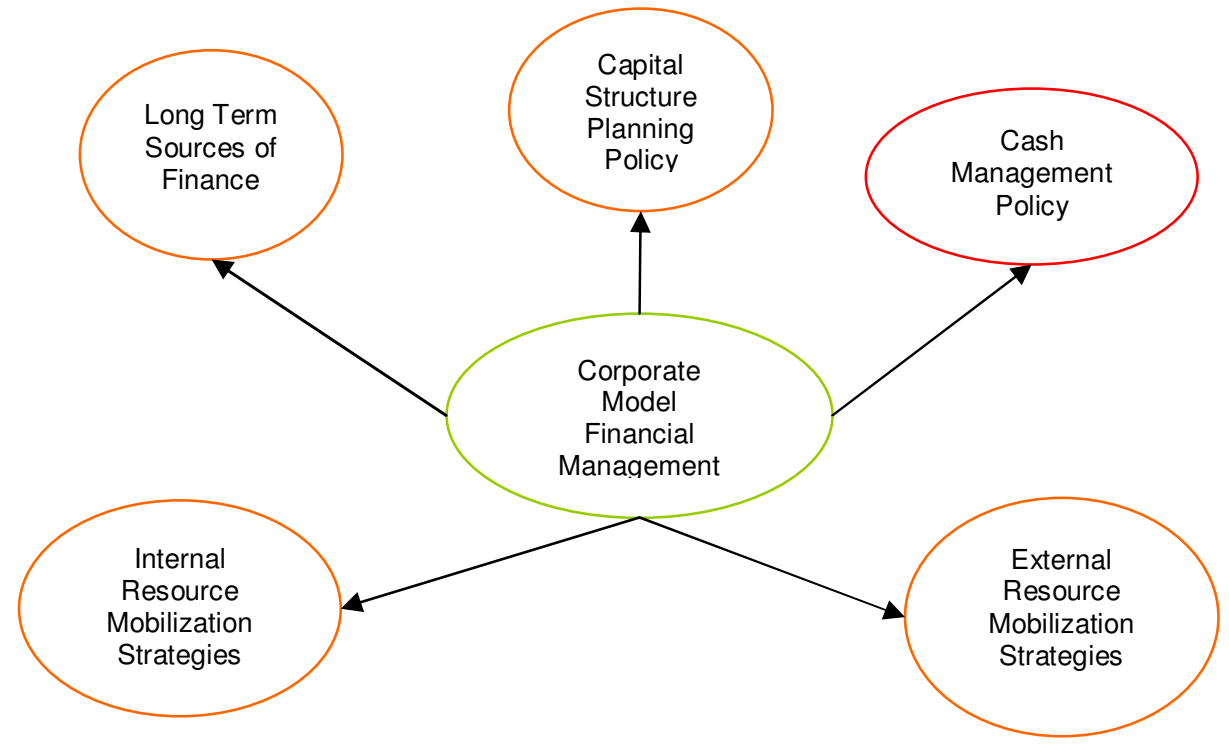

Figure 1: Institutional Income Diversification Model

\section{Step One: Adoption or Strengthening of a Corporate Model}

- Transformation of universities from the highly bureaucratic organizations they have been to less bureaucratic higher education corporations.

- Adoption of a Market culture which the corporate model nurtures.

- Pay attention to private sector principles of financial management.

- Discard Bureaucratic ritualism.

- Adopt corporate principles of organisation which maximize quick rational decision making and problem solving.

- Improvement of efficiency and effectiveness through adoption of a result-oriented culture that should be triangulated with a high concern for people.

- Development of appropriate and functional administrative structures which should be respected by all.

- Adoption of corporate principles of organisation which maximize quick rational decision making and problem solving.

\section{Step Two: Formation of a Comprehensive Financial Management and Control System}

- Improving financial management by carrying out regular expenditure forecasts.

- Developing a culture of budget discipline and proper accountability.

- Establishment of a policy that regards international students as forming part of a broader higher education export policy.

- Involving students in the financial resource mobilization and utilization activities.

- Reduction of expenditure through restructuring the financial management systems.

- But, improving the quality and quantity of the financial management team.

- Involve more people in the management of institutional finances

- Implement programme linked budgeting.

- Closing the loopholes that permit corrupt officials to misappropriate funds.

- Carry out regular internal and external Audits

Step Three: Resource Mobilization Strategies-Internal Income Generating Activities/ Initiatives

- Establishment of income generating activities such as: 
$>$ Consultancy services, conference facilities, endowments.

$>$ Short-term training courses, workshops and seminars.

$>$ Contract research projects.

$>$ Establishment of Night Classes, weekend and holiday programmes.

$>$ Programmes \& upcountry outreach centres.

$>$ Establishment of a policy of charging Parking fees on campus for visitors.

$>$ Recycling of waste paper, examination scripts, aluminium cans, old books, lab materials, etc.

- Establishment of commercial projects such as:

$>$ Poultry farms, piggeries, agricultural farms,

$>$ Investing in Public transport.

$>$ Construction of Petrol Stations, Supermarkets, Drive-in-Cinemas, Washing Bays,

$>$ Printing Services,

$>$ Catering Services,

$>$ Privatization of Halls of Residence through lease to private investors, Renting out to interested parties of physical facilities that are often underutilized such as Teaching Rooms, Lecture Halls, Laboratories, and Studios for media, Sports facilities, Social and Cultural rooms, etc.

\section{Step Four: Resource Mobilization Strategies: External Income Generating Activities/ Initiatives}

- Strategic acquisitions of other institutions.

- Institutional mergers to reap from the advantages of economies of scale.

- Investment in Treasury Bills, Bonds, long and short term convertible securities.

- Seek term loans from commercial banks which are repayable in periodic instalments.

- Negotiated financing from commercial Banks and Finance companies.

- Investment in real estate.

- Project financing in which a separate legal entity is formed to own the University project. Suppliers of Capital then look at the earnings stream of the Project for repayment of their loan or for the return on their equity investment.

- Form University Consortiums to spread risk and to finance University Projects.

\section{Step Five: Miscellaneous Strategies for Mobilization of Financial Resources}

- Seeking assistance through affiliation, from established foreign institutions.

- Developing a symbiotic relationship with the private sector and industry.

- Special appeals for raising funds from the local and international donor community.

- Developing stronger relations with the donor community through networking activities to make solicitation of donations and grants easy.

- Developing stronger relations with the government through mobilization of support for National Development Plans to attract government funding.

\section{Management and Cost-Benefit Implications}

In spite of the proposition that bureaucracy may have been the most efficient means of organization for the achievement of educational institutions' objectives and goals, there are weaknesses in the bureaucratic model that do not encourage innovativeness. These weaknesses are crucial to the effective and efficient financial management of the challenges and opportunities created by the new societal demands, developments in the Higher Education sector and circumstances of the $21^{\text {st }}$ Century. As Universities are transformed from government controlled bureaucracies to quasicorporate bodies, there is need to transform the way they operate. Competition between universities represents the most important contribution to the efficiency of the University system. To remain competitive Universities must adopt the corporate model of financial management which provides an enabling environment for the diversification of revenue. 
When Higher Education Economists carryout a cost-benefit analysis for investment in Universities they compare the total cost of Higher Education either to the individual or to the society with the expected returns from investment in Higher Education. This provides a measure of the private or social measure of returns on investment in university Education which shows the relative profitability of Higher Education and other forms of investment. The benefits of Higher Education are measured in terms of extra life-time, increased incomes or earnings enjoyed by University graduates compared to workers with lower levels of education or illiterate workers. These benefits mean that Higher Education is a profitable form of investment offering returns as higher as or even higher than the average rate to physical capital in other sectors. But, the profit motive must be balanced with quality assurance and the expectations of society.

\section{Importance of Financial Resource Management to a University Leader}

Financial resource mobilization, utilization and management have been defined in different ways. To some, it is management of inflows and outflows of money in an institution. To others it is financial accounting. Common to all is money because it is the lifeline of any university, or any other organization. If money is mismanaged in a university, the activities of the institution are adversely affected (Ssebwaluunyo, 2005). Efficient financial resource mobilization, utilization and management ensure the financial health of an institution. The financial health of a university includes the physical cash situation, that is, physical assets, financial resources and liabilities of the institution. Financial resource management in a university is not just receiving and spending money; it concerns itself with actual inflows and outflows of cash, as well as, the management off any claims that have a financial cost implication to the finances of the university. In the final analysis, efficient financial management is all about making the correct decisions after considering all the possible alternatives.

The main purpose of mobilizing and managing financial resources is to ensure an efficient, orderly and best way of sustainable long term running of a university. It achieves its purpose by mobilizing and applying resources, auditing them and budgeting for them; mobilizing the various financial resources involves planning the best way of mixing resources to achieve the creation of a sustainable financial base for running a university. This can be mathematically expressed as follows:

$$
\sum 5 \mathrm{Ms}+\mathrm{m}+\mathrm{a}+\mathrm{c}=\mathrm{CWs}
$$

[where the five Ms represent Money, Method, Men, Material, Machines, $\mathrm{m}=$ method, $\mathrm{c}=\mathrm{control}$, $\mathrm{W}=$ wealth, a=application, $\mathrm{s}=$ sustainability, $\mathrm{C}=$ Creation $]$

Good financial management achieves its purpose and objectives of creating sustainable institutional wealth and development by mobilizing and applying resources, auditing and budgeting. Mobilizing the various resources involves planning the best way of mixing the various resources to achieve the creation of value and therefore sustainable wealth and development for a university.

\section{Principles of Financial Resource Mobilization, Utilization and Management in a University} According to Nkata (2005) the cardinal principle of financial resource mobilization and management is to cultivate the right attitudes toward the income and expenditure of the institution. Perceiving the purpose of resource mobilization exclusively as the maximization of shareholder value and wealth or for creating share price appreciation in the short run in a university can affect quality. True, the principle of maximization of shareholder wealth provides a rational guide for running universities that are run as businesses and of the efficient allocation of resources in society, but it raises ethical questions, as well as create quality assurance concerns. University proprietors should strive for quality in order to attract clients or customers.

Other principles include goal-setting, programming and information, as well as social responsibility. Developing a positive attitude does not merely imply refraining from embezzlement; it means a deliberate and often selfish misuse or misallocation of resources. Resource wastage is also a negative attitude. Determining and forecasting probability of occurrences that have a financial cost implication to the university is an important principle. A positive attitude towards financial resources means perceiving financial resources in the context in which those resources 
were meant to be managed. Frugality not meanness is also a useful principle of financial resource mobilization, utilization and management; starving employees, that is, not paying them on time, affects moral, productivity and ultimately quality itself.

It has long been observed that the separation of ownership and management control of universities creates potential conflicts between the owners and the professional managers because of divergences in interest, yet in the interests of quality assurance, this is a priority area for the regulatory body that insists that ownership of private universities must be separated from their management. With the liberalization of and privatization of higher education, entrepreneurs have established private universities for the purpose of making profits. But unlike other businesses, education as a business has social responsibility implications. Profits cannot be made at the expense of quality without attracting the censure of public opinion, if not the long arm of the law. Whereas the entrepreneur may have set up the university for the purpose of making money, he/she cannot maximize profits without due consideration for the societal responsibility of delivering quality education and promoting the development needs of society. It has been observed that only a few professional managers in the private university industry can risk putting their jobs on the line by opposing the selfish demands of their bosses and sometimes make decisions which have financial cost implications that compromise the delivery of quality education. However, professional managers' risk putting their reputation on the line if they take decisions that compromise quality assurance.

The Executive Director of the National Council for Higher Education, Professor Kasozi has the uphill task of persuading the Private University owners to pull out of direct control of the administration of their enterprises and does not seem to be making much progress with Universities at the lower end of the scale. Organizational structure and management charts are fabricated overnight when notice of an impending inspection visit is given. By the time the NCHE Assessors or monitoring team arrives everything they need is on paper and sometimes absentee professors and managers are in situ to answer any questions that the team might wish to ask! Staff lists contain individuals or people whom even long serving members of staff have never seen and some private university owners treat the institutions as a side business similar to an Indian 'Dukawallah', from which they siphon money whenever they feel like it and without observing any universally accepted accountability practices. But there are instances too when professional managers may make financial decisions that are in the manager's own self interests and not those of either the owners of the university or society as whole. The manager may pursue policies that are primarily intended for creating wealth for him rather than achieving the objectives for which a University may have been set up by the founding body or the benefit of society as a whole.

Efficiency in financial resource management in a university depends on how well the manager performs his duties and carries out his financial responsibilities. In the long run the personal needs and goals of the financial manager obliges or forces him to strive for efficiency which will in turn result in the creation of value and prestige for the university if it records good results in examinations and therefore wealth for the owners because demand for enrolment in the institution will go up resulting into increased esteem for the institution. An increase in enrolment means a rise in income for the owners and it would be in the best interests of both for the professional manager to continue to make financial decisions that create sustainable wealth for the owners. But, to be sure that the manager does not stray away from the purpose and objectives for which the institution was set up, control measures such as performance contracts can be complemented by a system the corporate world calls bonding.

\section{Conclusions}

It is difficult to make generalizations because universities vary in size, location, levels and organizational set-up, the political and financial environment in which they operate. However, most educational institutions operate under scarce resources but the more affluent a university is the more its expectations and the more the need for mobilizing more funds to run it. University leaders must 
make the best use of the available resources before embarking on any financial resource mobilization drive. This requires the leaders to be aware of the general principles of financial management and to practice them religiously. The appropriateness of these principles depends on the good structuring of the financial resource management environment or system. Any management principles that violate the system are inappropriate. The structure of the financial system introduces the principles not vice versa. University managers should not shy away from doing many of the things Corporate Managers do such as investing in revenue generating projects even though simply stated the cost of earning revenue is referred to as an expense by accountants/auditors and this frightens them.

\section{Note}

This article is based on a workshop paper delivered at the National Council for Higher Education Workshop to find ways of funding higher education institutions in Uganda (held at the Faculty of Food Science and Technology at Makerere University on July $30^{\text {th }} 2007$ ).

\section{References}

Horne, V., 2003. Financial management and policy. New Delhi: Prentice- Hall of India.

Kasozi A. B. K., 2003. University Education in Uganda: Challenges and opportunites. Kampala: Fountain Publishers.

Nkata, J., 2005. Unpublished lecture notes.

Pandey, I. M., 2001. Financial management. Vikas. New Delhi: Publishing PVT Ltd

Wanambi, N. K., 2004. The financing of institutions of higher education: The case of funding mechanisms to produce change and diversification of institutional incomes. Paper delivered at a National Council for Higher Education Workshop held at Jinja, July 2004.

\section{Author Biography}

Ambassador Samuel H. Baligidde is a former career diplomat. Currently, he is the Director of the East African School of Diplomacy, Governance and International Studies. He holds an Honours Bachelor's degree in Political Science and Public Administration from Makerere University; Master's degrees in Education Management and Public Administration; and a professional certificate for Commercial Attaches and Economic Counsellors. 